forts which had been situated far down the river, about ten or eleven miles above its mouth, in the angle formed by the river and the mouth of Octoraro Creek, on the eastern side of the river. These deponents all refrained from expression of opinion regarding the name of the Indians who were the builders of these forts, and it is not unlikely that they were not called upon to answer this question for fear that the answer might be that these Indians were not Susquehannocks, as indeed was most likely the case.

Elizabeth Murphy, aged forty years, deposed that her father, John Erskine, who ". . had lived at the same place many years by license of the Indians," had shown her there the ruins of an Indian fort and had informed her that ". . . there had been a great Battle fought there, and shewed her the Bones of several Persons buried in the Cliffs of the Rocks, which he said were the bones of Indians slain in that Battle." Margaret Allen, sister of Mrs. Murphy, testified to having seen great numbers of human bones at the place, ". . . which her father informed her, had been slain in many Battles fought there," and that "... she pickt up great numbers of stone arrow points and stone hatchetts there."

John Hans Steelman, a well known Indian trader, aged eighty-five years, deposed that forty or fifty years before Jacob Young, another and in his day quite famous trader, had showed him the ruined fort, where Young had pointed out "... several dead mens bones and told him a great battle had been fought there by the Indians." 175

No doubt all of these Indians who had fallen in these battles had been buried, but whether all had been interred in the "cliffs of the rocks" does not appear. These rocky hillsides, rising from the river flats, run more or less parallel with the river at a distance of about one-eighth of a mile. There is reason to believe that these flats are rich in Indian remains, but no scientific effort to find them has ever been made. The shores of the river between the Conowingo power dam and the mouth of Octoraro Creek are the favorite resorts of local collectors. It seems strange that the Maryland Archives show no certain evidence of trouble or of diplomatic relations between the Province of Maryland and the Indians of these two forts, whoever they were.

William B. Marye

Baltimore, Maryland

\title{
The Iroquois AND the Birdstone
}

In the last October issue of this journal appeared a letter from Mr. Ralph H. Whitehead of Boston, Pennsylvania, under the caption, The Birdstone and Its Probable Use.

On rather specious grounds $\mathrm{Mr}$. Whitehead has attempted to substantiate the old theory which identifies the birdstone as a canoe-prow ornament. With this part of his discussion I am not concerned, having no valid notions concern-

${ }^{175}$ Pennsylvania Archives, Second Series, Vol. 16, pp. 523-524, 525. 
ing the probable function of this artifact; but I wish to correct the statement, admittedly suppositional, " ... that the development of the birdstone, along with certain other ceremonial forms of polished slate, is a cultural manifestation of the Iroquoian tribes, introduced by them and accepted with certain modifications by various tribes with whom they came in contact."

This is directly contrary to the known facts. Indeed, if any one point is established in northeastern archaeology, it is that the so-called "problematical" forms, chiefly of polished slate, are not of Iroquois provenience. Parker, sixteen years ago, pointed this out. Except for an occasional gorget, almost certainly intrusive, neither he, Skinner, Harrington, Wintemberg, nor any other worker, including the writer, has ever found such an object in the middens, pits, or graves of an Iroquois station.

In New York State our excavations have so far shown the birdstone to be a trait of but two horizons; namely, the Pt. Peninsula and Middlesex foci of the Vine Valley aspect, formerly called by us the Second Algonkin Period. It has been found associated, here and elsewhere in the northeast, with gorgets of several forms, the boatstone, bar amulet, two varieties of tubes, notched and triangular projectile points, marine-shell beads of several kinds, large prominently barbed harpoons, antler tool handles, a type of hafted beaver-tooth "engraver," the platform and elbow pipes, native copper articles, rude pointedbased pottery, and several other artifact types, not alone in pits but as grave goods on such sites as that at Swanton, Vermont, ${ }^{176}$ and that on the west shore of Chaumont Bay, Jefferson County, New York. ${ }^{177}$

Since such sites unequivocally antedate the arrival of the Iroquois, and manifest, moreover, no trait linkage with that people, they could not have transmitted the birdstone to other Indians, particularly since there is every reason to believe that it was never used by them.

William A. Ritchie

Rochester Museum of Arts and Sciences

Rochester, New York

\section{REgaRding KNOTTED LOOPING}

Miss Singer's contribution to "Correspondence" in the last issue of AMERICAN ANTIQUITY asked two questions and offered a criticism. In response to the first question, concerning the appearance of knotted looping, which Miss Singer correctly figures in her sketch, her attention is called to Fig. 3, 6a, in the article cited, which shows the same knot labeled "knotted looping." As to the knot employed, my work with prehistoric fabrics of this sort and their impressions-would not permit the dissection of the knots. I also would be interested to know their nature.

${ }^{178}$ Willoughby, C. C., Antiquities of the New England Indians, Peabody Museum at Harvard, p. 85, 1935.

${ }^{177}$ See an article by the writer in AMERICAN Antroutry, this issue. 